Article

\title{
Quantifying Land Use Land Cover Changes in the Lake Victoria Basin Using Satellite Remote Sensing: The Trends and Drivers between 1985 and 2014
}

\author{
Robinson Mugo ${ }^{1, *(\mathbb{D}}$, Rose Waswa $\left.{ }^{1}{ }^{(}\right)$, James W. Nyaga ${ }^{1}$, Antony Ndubi ${ }^{2}{ }^{\circ}$, \\ Emily C. Adams ${ }^{3,4}$ (D) and Africa I. Flores-Anderson ${ }^{3,4}$ \\ 1 Regional Centre for Mapping of Resources for Development, Nairobi 00618, Kenya; \\ rwaswa@rcmrd.org (R.W.); jnyaga@rcmrd.org (J.W.N.) \\ 2 Food and Agriculture Organization of the United Nations, Somalia Programme, Nairobi 00100, Kenya; \\ antony.ndubi@fao.org \\ 3 NASA SERVIR Science Coordination Office, Marshall Space Flight Center, Huntsville, AL 35811, USA; \\ emily.c.adams@nasa.gov (E.C.A.); africa.flores@nasa.gov (A.I.F.-A.) \\ 4 Earth System Science Center, The University of Alabama in Huntsville, Huntsville, AL 35899, USA \\ * Correspondence: rmugo@rcmrd.org
}

Received: 10 June 2020; Accepted: 25 August 2020; Published: 1 September 2020

\begin{abstract}
The Lake Victoria Basin (LVB) is a significant resource for five states within East Africa, which faces major land use land cover changes that threaten ecosystem integrity and ecosystem services derived from the basin's resources. To assess land use land cover changes between 1985 and 2014, and subsequently determine the trends and drivers of these changes, we used a series of Landsat images and field data obtained from the LVB. Landsat image pre-processing and band combinations were done in ENVI 5.1. A supervised classification was applied on 118 Landsat scenes using the maximum likelihood classifier in ENVI 5.1. The overall accuracy of classified images was computed for the 2014 images using 124 reference data points collected through stratified random sampling. Computations of area under various land cover classes were calculated between the 1985 and 2014 images. We also correlated the area from natural vegetation classes to farmlands and settlements (urban areas) to explore relationships between land use land cover conversions among these classes. Based on our land cover classifications, we obtained overall accuracy of $71 \%$ and a moderate Kappa statistic of 0.56. Our results indicate that the LVB has undergone drastic changes in land use land cover, mainly driven by human activities that led to the conversion of forests, woodlands, grasslands, and wetlands to either farmlands or settlements. We conclude that information from this work is useful not only for basin-scale assessments and monitoring of land cover changes but also for targeting, prioritizing, and monitoring of small scale, community led efforts to restore degraded and fragmented areas in the basin. Such efforts could mitigate the loss of ecosystem services previously derived from large contiguous land covers which are no longer tenable to restore. We recommend adoption of a basin scale, operational, Earth observation-based, land use change monitoring framework. Such a framework can facilitate rapid and frequent assessments of gains and losses in specific land cover classes and thus focus strategic interventions in areas experiencing major losses, through mitigation and compensatory approaches.
\end{abstract}

Keywords: remote sensing; Landsat; Lake Victoria Basin; land use land cover

\section{Introduction}

The Lake Victoria Basin (LVB) land mass covers approximately 184,200 square kilometers, traversing five East African countries (Kenya, Uganda, Tanzania, Rwanda, and Burundi) [1]. It is home 
to an estimated 35 million people, with the registered population growth within the 100-km buffer zone around Lake Victoria reported to be significantly higher than that of the rest of Africa. This is due to the wealth of natural resources, economic benefits, and ecosystem services that the basin offers [1]. The LVB contains the world's largest tropical lake [2] and supports diverse socioeconomic activities, among them agriculture, livestock keeping, and fishing activities, and thus is a significant resource for food security for the five countries. It is also important for energy production, domestic and irrigation water, shelter and transport, and recreation [3].

The demand for land and its associated resources and ecosystem services continues to grow all over in East Africa, which drives human related land use changes and subsequent land cover change over short and long-term scales. Land use land cover (LULC) change in East Africa is a widely studied subject [4-7], and a number of factors have been identified as key drivers of land use land cover change [1]. There are recent continental scale studies [5,8], national, basin, or sub-basin scale studies [9,10], as well as regional efforts [11]. Some work has focused on relatively small riverine catchments, with a focus on the local drivers of land use change $[10,12,13]$. Attention has also been leveled at the linkages between climate change and variability in land use change $[4,11]$ while others have investigated the relationships between population growth, economic development, and environmental sustainability [6,14]. In almost all the papers, the authors agree on the key drivers of land cover change, mainly land use conversions to agriculture and urbanization (settlements) $[1,13]$. These researchers have provided invaluable information on the drivers of land use change over time and in some instances advocated for specific mitigation measures for reducing massive land use changes which impact negatively on ecosystem services and the climatic regime of the region. While the drivers are well recognized, correlations among land cover types at a basin scale are yet to be shown. In addition, for the LVB, gaps still abound in land use land cover changes in recent decades and the functional relationships between the area under natural vegetation and that under croplands and urbanized zones at a basin scale. In a basin shared by five countries, land use policies and business regimes influencing land cover changes vary. Furthermore, interpretations of land cover classes across the countries often differ, thus affecting the computation of harmonized estimates of land cover change. This can also adversely affect the quantification of ecosystem services offered by natural land cover, thus leading to underestimation of the value of these services. In the absence of regionally acceptable land cover classifications, the assessment of gains and losses of important ecosystems would not be feasible, and this hampers efforts in joint land use management and conservation at regional level. To address such concerns and create consistency, it is necessary to create a basin wide, standardized land cover map using an internationally recognized classification system over a period of approximately 30 years. Towards this end, our specific objectives were (i) to quantify land use land cover change from 1985 to 2014 using an internationally recognized classification system in the LVB and (ii) to investigate the spatial patterns and land cover changes per class and assess the relationships between areas under different land cover classes.

\section{Data and Methods}

\subsection{Study Area}

The LVB $\left(184,200 \mathrm{~km}^{2}\right.$ ) ranges in altitude from 1100 to over $4000 \mathrm{~m}$ (highlands in Rwanda, Elgon and Mau escarpment) above sea level and has a variety of terrains that are characterized by mountains to gentle plains in some areas (Figure 1). The steep highlands are often affected by erosion and landslides during the rainy seasons $[15,16]$. The soil types are variable and are largely influenced by the volcanic activity of the Great Rift Valley. Soil type and fertility is a major determinant of cropping types and other land use types such as livestock keeping. The vegetation types across the basin include montane forests, savannahs, grasslands, wetlands, woodlands, and croplands (tea, cereals, coffee etc.) [1]. Vegetation cover is influenced by soil types, climatic patterns (precipitation and temperatures), and human activity over time [3]. Lake Victoria and its network of rivers and streams 
constitute the major hydrological features in the basin. These are important sources of water for various uses within the basin (domestic, agriculture, transport, etc.). The lake and rivers are also major conduits of pollutants and sediment transport and thus an important repository for human, agricultural, and industrial waste [1,17]. The basin is also significant for biodiversity and thus plays a critical role in conservation and promotion of tourism activities [3]. The LVB experiences a complex climatic system which is influenced by a number of inter-tropical convergences and the Indian Ocean Dipole [18,19], which creates mainly two rainy and dry seasons [18]. Over the years, land use and land cover has evolved within the basin due to a number of factors. For instance, major cities (Jinja, Kisumu, Mwanza) in each of the East African countries have grown over the years, accompanied by upcoming towns in the outskirts. Land use and land cover change in the basin is one of the key drivers of water quality degradation in Lake Victoria and its tributaries [20].

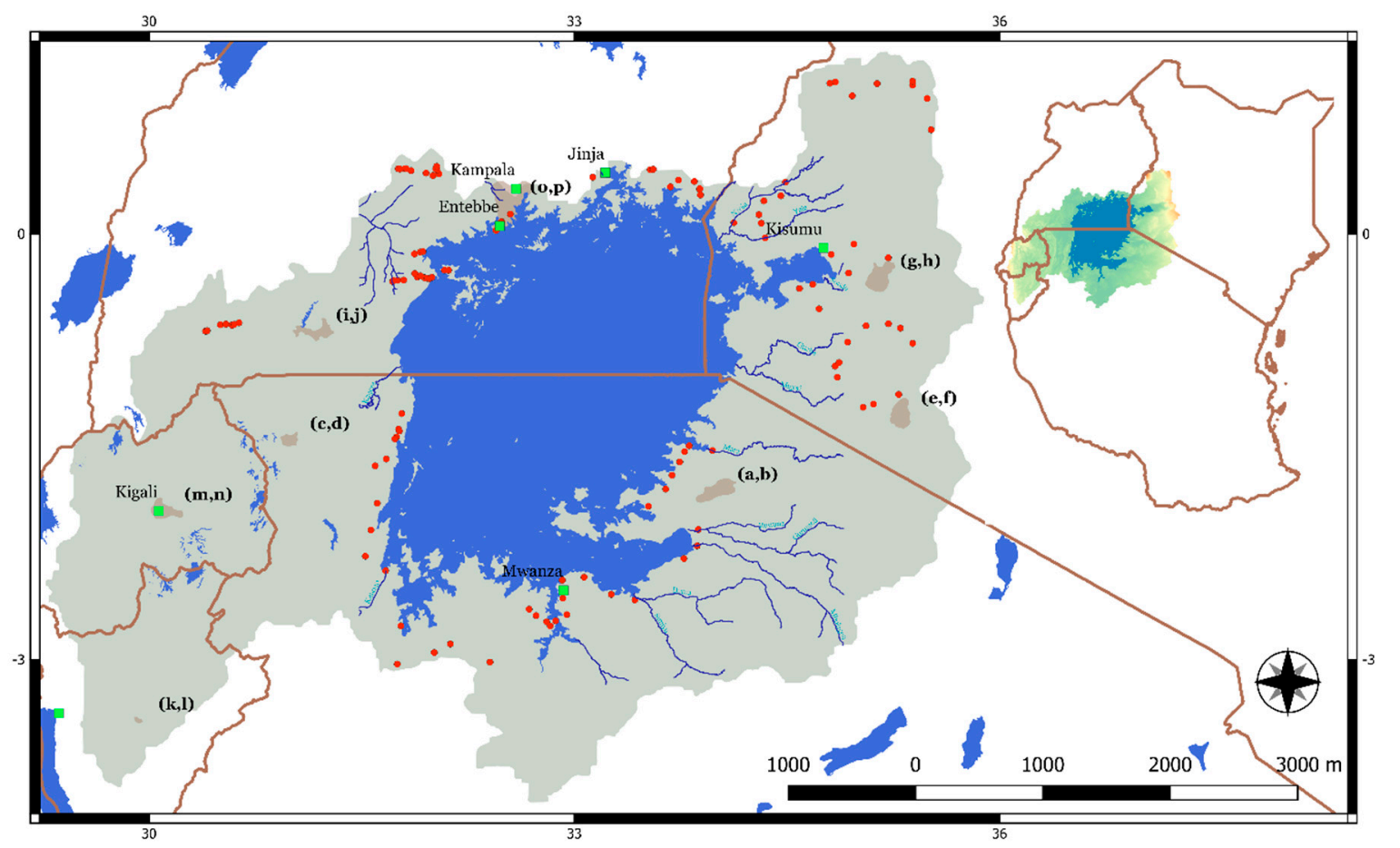

Legend

$\begin{array}{llll}\text { - Rivers } & \text { " Sample Points } & \text { Lakes } & \text { Locations with remarkable LULC } \\ \text { - International Boundary } & \text { - Towns } & \text { Lake Victoria Basin Area }\end{array}$

Figure 1. A map of the Lake Victoria Basin, showing locations where reference data were collected (red dots) in parts of the basin in Uganda, Kenya, and Tanzania. The brown polygons marked with letters show selected locations where change in land cover is remarkable.

\subsection{Earth Observation Data Analysis}

We analyzed satellite remote sensing data for several epochs in the LVB. A total of 118 Landsat 2, 3, 4, 5, 7, and 8 (MSS, TM, ETM+, and OLI sensors) scenes were downloaded from the USGS Global Visualization Viewer (https://glovis.usgs.gov/) for the years 1985, 1990, 1995, 2000, 2010, and 2014, with approximately 19-20 scenes covering the area of interest defined as the LVB. The specific scenes covered the following paths and rows on the world reference system (WRS): 169/059-63, 170/059-63, 171/061-63, 172/060-63, and 173/060-63. The Landsat data stream was deemed appropriate for mapping basin scale land use changes at $30 \mathrm{~m}$ resolution, with minimal bias from seasonality. Image selection was based on data availability within the dry season of the area under consideration, which presented the best chance of minimizing cloud contaminated images. In cases where images from a target year were not available, the images from the previous or next year were used (no more than 2-3 image 
substitutions for the target year). We adopted the land use classification approach described by the Food and Agriculture Organization's Land Cover Classification System (FAO-LCCS), which uses the dichotomous and modular phases in succession to define land cover classes [21]. Slight modifications were made to accommodate classes that are applicable to the study area and reflect particular land use changes with respect to ongoing human activities. This approach was found necessary to define regionally consistent land uses in a basin whose geographical coverage traverses 5 countries, where national definitions of various land use categories may vary considerably. The land use land cover classes considered in this work were bare soils, urban areas, wetlands, waterbodies, small scale farmlands, large scale farmlands, large scale farmlands (plantation), open grasslands, closed grasslands, open woodlands, closed woodland, and indigenous forests. We adopted definitions of land use land cover classes described by the Intergovernmental Panel on Climate Change (IPCC) (https://www.ipcc-nggip.iges.or.jp/public/gpglulucf/gpglulucf_files/Chp2/Chp2_Land_Areas.pdf) and expanded the definitions of farmlands, grasslands, and woodlands to make the classifications more responsive to land use in the region and also communicate variations of these land use types in the Lake Victoria Basin. Large scale farmlands are mainly tea, coffee, rice, and sugarcane plantations, while small scale farmlands are characterized by small holder farms practicing subsistence agriculture for food crops. Grasslands and woodlands are an important type of land cover, especially for the areas south east of Lake Victoria, and the cover can vary depending on the level of disturbance. For consistency across the basin, maps were georeferenced to the WGS84 projection.

Image processing and classification was conducted in ENVI version 5.1 (Exelis Visual Information Solutions, Boulder, CO, USA), where geometric and radiometric correction, band stacking, visual interpretation of images, and creation of regions of interest (ROI) useful for classification was done. The analysts conducting image classification had a good understanding of the region, and their knowledge was useful in visual feature recognition, aided by high resolution imagery available in Google Earth. This work applied the maximum likelihood classification algorithm (supervised classification), which is a pixel-based classification that classifies images based on the homogeneity of image pixel spectral information. Classification was done in ENVI, where the ROI polygons picked by the analysts were used as training areas for image classification. The classified images were then taken through post classification processing and assignment of consistency codes (using a decision tree approach) for respective classes before mosaicking of individual scenes. A post classification smoothing was done by applying a $3 \times 3$ kernel filter to minimize the "salt and pepper" effect associated with pixel-based methods.

\subsection{Reference Data Collection and Accuracy Assessment}

A team of reference data collectors visited parts of the basin that were accessible in Kenya, Uganda, and Tanzania (Figure 1). Prior to the field visits, the analysts discussed and built a consensus around the identification and documentation of land cover classes in the field, following principles of a response design [22]. The number of reference points collected per class was also determined by the accessibility of sites and cost of field visits [22]. The ArcMap software was used to prepare a shapefile of ROIs from which random points would be selected for validation and accuracy assessment. This shapefile was then loaded in ENVI and overlaid on the classified image, from which selected areas of the classified image were chosen as candidate sites for the creation of a representative sample of points to be used for accuracy assessment. A stratified random sample of selected classes was then processed and exported to a shapefile, from which they were loaded into a GPS unit, ready for use in the field. The data collectors used handheld GPS gadgets to locate and mark distinct land cover classes within the basin. Concurrent with the GPS points, the data collectors also took photographs of land cover, which were further used to help in interpretation of the classified images for the 2014 epoch. This was deemed necessary to minimize geolocation errors and interpreter uncertainty [22]. A total of 124 GPS points covering major land cover types in the basin were collected for accuracy assessment as shown in Figure 1. The overall accuracy and kappa statistics of agreement for the 2014 land cover map 
were computed. A change detection analysis was conducted between selected epochs using ArcGIS version 10, and land use cover change matrices were extracted to determine land use cover transitions in the basin. Our analysis workflow is illustrated in Figure 2.

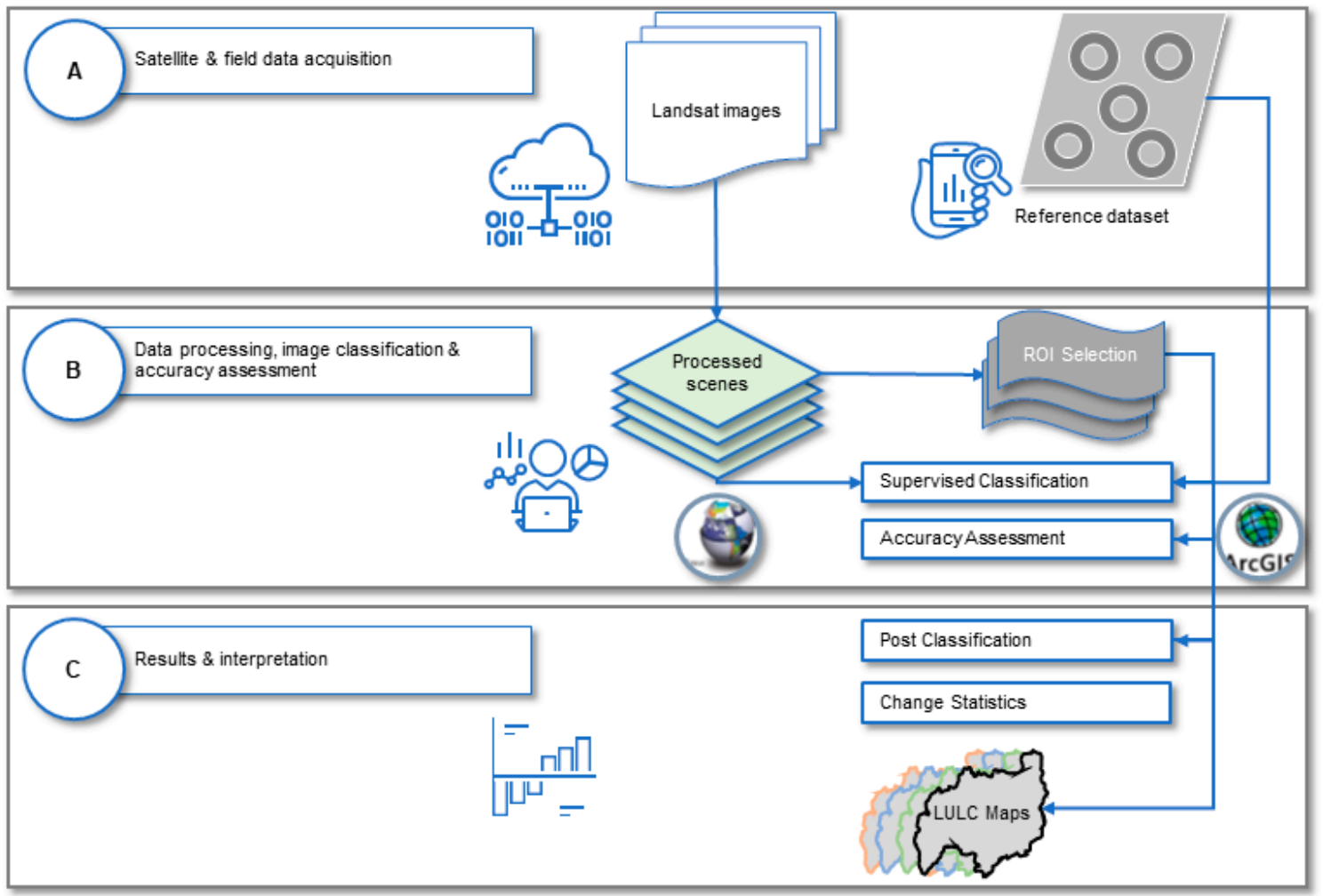

Figure 2. Workflow illustrating the Landsat image processing and analysis to develop land use land cover maps (LULC) for the Lake Victoria Basin (LVB).

We derived the hectarage for each land cover class for each epoch $(1985,1990,1995,2000,2010$, and 2014) and subsequently computed the percent increase or decrease in area per land cover class for each epoch year, using 1985 as the base year. We also regressed the area under indigenous forests, open woodlands, wetlands, closed woodlands, largescale farmlands (plantation), largescale farmlands, and closed grasslands against either urban areas or small scale farmlands. Regression analysis enabled us to measure the statistical relationships between land cover patterns elucidated in our work. We hypothesized that human activity (e.g., urban growth, expansion of small scale agriculture, deforestation) in the LVB could be correlated with a decline in natural vegetation, which is a phenomenon witnessed globally [23].

\section{Results}

Our results show that there have been remarkable land cover land use changes in the Lake Victoria Basin, detectable from satellite remote sensing and in-situ observations over the last 30 years. The land cover maps for 1985, 1990, 2000, 2010, and 2014 are shown in Figure 3. The overall accuracy for the 2014 epoch for which the field data were available was 71\% (Table 1), with a kappa score of 0.56 . The proportion of each land cover class as percentage of the total area in 1985 and 2014 is shown in Figure 4, indicating increases in the area under small scale farmlands. The general trend over the years indicates that, while the area under small scale farmlands and urban areas continues to grow, that under indigenous forests, open and closed woodlands, wetlands, and open grasslands is declining (Figure 4). Figure 5 emphasizes snapshots of selected areas (whose locations are shown in Figure 1) across the land cover classification spectrum where change is remarkably visible. 
Table 1. Confusion matrix between interpreted and validation results for 2014 .

\begin{tabular}{|c|c|c|c|c|c|c|c|c|c|c|c|c|c|c|}
\hline $\begin{array}{l}\text { Land Use Land } \\
\text { Cover Class }\end{array}$ & $\begin{array}{c}\text { Bare } \\
\text { Soil }\end{array}$ & $\begin{array}{l}\text { Urban } \\
\text { Areas }\end{array}$ & Wetland & Waterbody & $\begin{array}{l}\text { Small Scale } \\
\text { Farmlands }\end{array}$ & $\begin{array}{l}\text { Large Scale } \\
\text { Farmlands }\end{array}$ & $\begin{array}{l}\text { Large Scale } \\
\text { Farmlands } \\
\text { (Plantation) }\end{array}$ & $\begin{array}{c}\text { Open } \\
\text { Grasslands }\end{array}$ & $\begin{array}{c}\text { Closed } \\
\text { Grasslands }\end{array}$ & $\begin{array}{c}\text { Open } \\
\text { Woodland }\end{array}$ & $\begin{array}{l}\text { Closed } \\
\text { Woodland }\end{array}$ & $\begin{array}{l}\text { Indigenous } \\
\text { Forest }\end{array}$ & TOTAL & $\begin{array}{c}\text { Producer's } \\
\text { Accuracy } \\
\text { (\%) }\end{array}$ \\
\hline Bare Soil & 1 & & & & 1 & & & 1 & & 1 & & & 4 & 25.00 \\
\hline Urban Areas & & 7 & 1 & & 1 & & & & 1 & & & & 10 & 70.00 \\
\hline Wetland & & & 5 & & 2 & & & 1 & 1 & & & 2 & 11 & 45.45 \\
\hline Waterbody & & & & 1 & & & & 1 & & & & & 2 & 50.00 \\
\hline Small Scale Farmlands & 2 & & & 2 & 61 & & 3 & & & & & & 68 & 89.71 \\
\hline Large Scale Farmlands & & & & & & 2 & & & & & & & 2 & 100.00 \\
\hline $\begin{array}{l}\text { Large Scale Farmlands } \\
\text { (Plantation) }\end{array}$ & & & & & & & 1 & & & & & & 1 & 100.00 \\
\hline Open Grasslands & & & & & 3 & & & 3 & & 1 & & 1 & 8 & 37.50 \\
\hline Closed Grasslands & & & & & & & & 1 & & 1 & & & 2 & 0.00 \\
\hline Open Woodland & & & & & 3 & & & 2 & 2 & 3 & & & 10 & 30.00 \\
\hline Closed Woodland & & & & & & & & & & & 1 & & 1 & 100.00 \\
\hline Indigenous Forest & & & 1 & & & & 1 & & & & & 3 & 5 & 60.00 \\
\hline TOTAL & 3 & 7 & 7 & 3 & 71 & 2 & 5 & 9 & 4 & 6 & 1 & 6 & 124 & \\
\hline $\begin{array}{l}\text { Consumer's Accuracy } \\
(\%)\end{array}$ & 33.33 & 100.00 & 71.43 & 33.33 & 85.92 & 100.00 & 20.00 & 33.33 & 0.00 & 50.00 & 100.00 & 50.00 & & \\
\hline
\end{tabular}



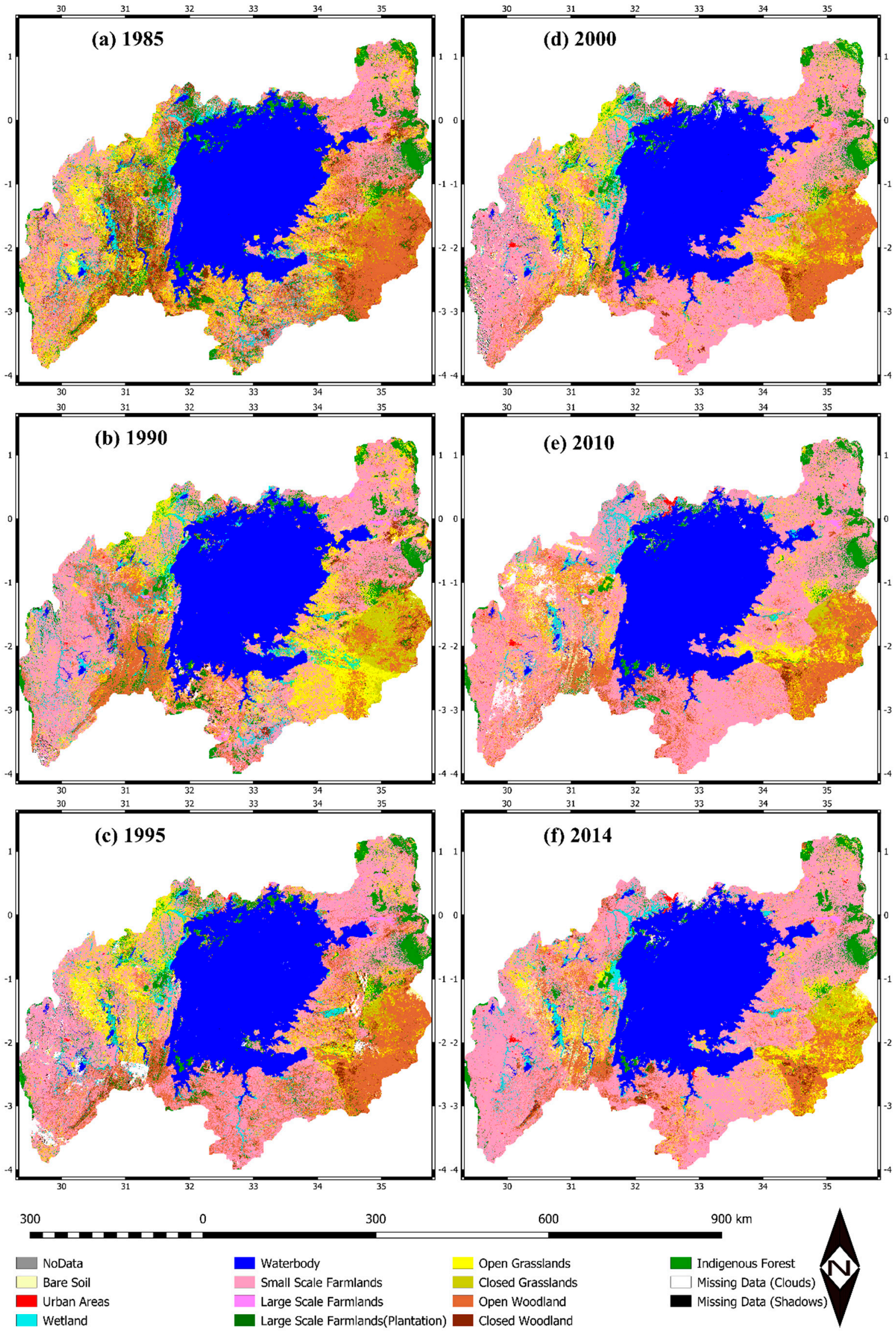

Figure 3. Land cover maps of the LVB for (a) 1985, (b) 1990, (c) 1995, (d) 2000, (e) 2010, and (f) 2014. 


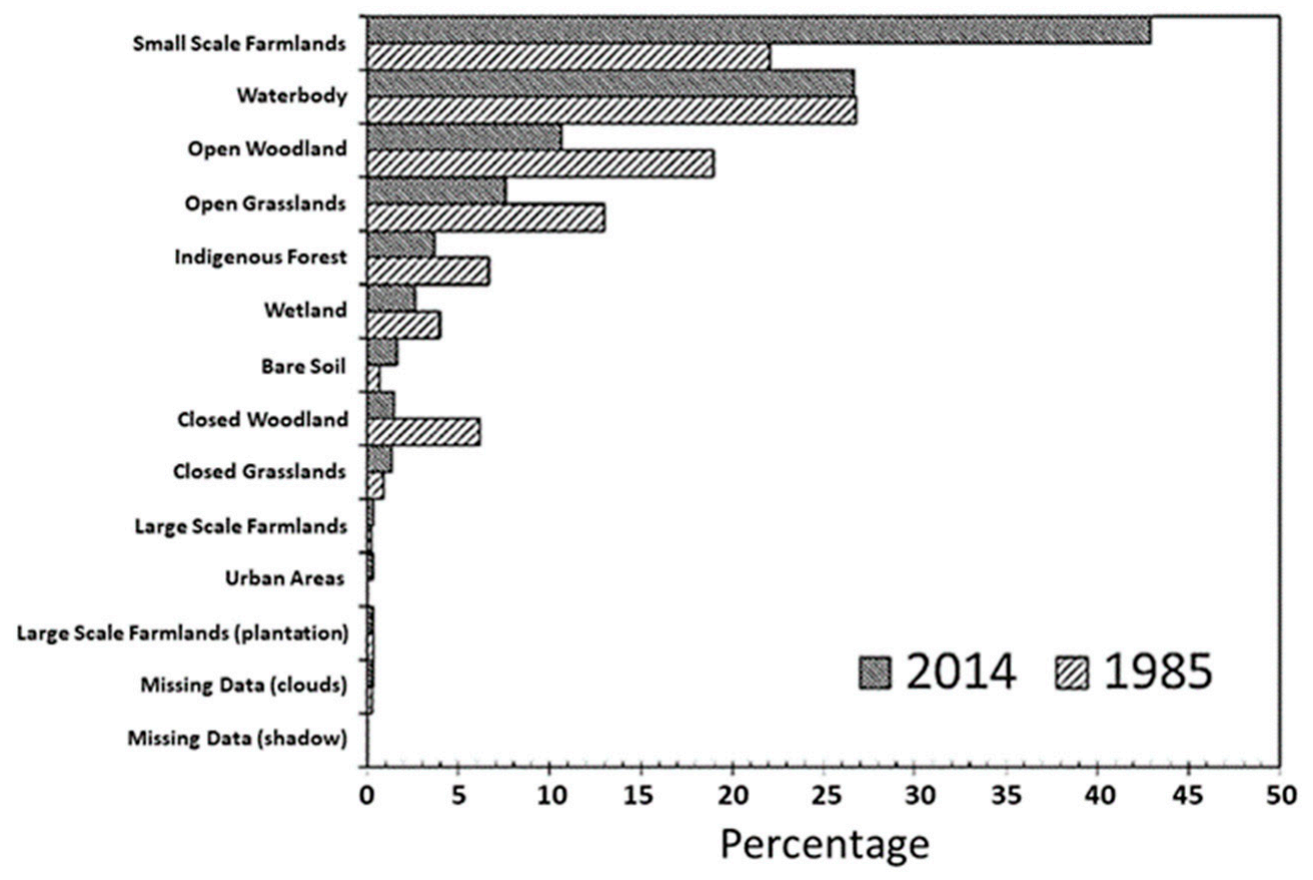

Figure 4. Proportion of each land cover class as a percentage of the total area in 1985 and 2014.

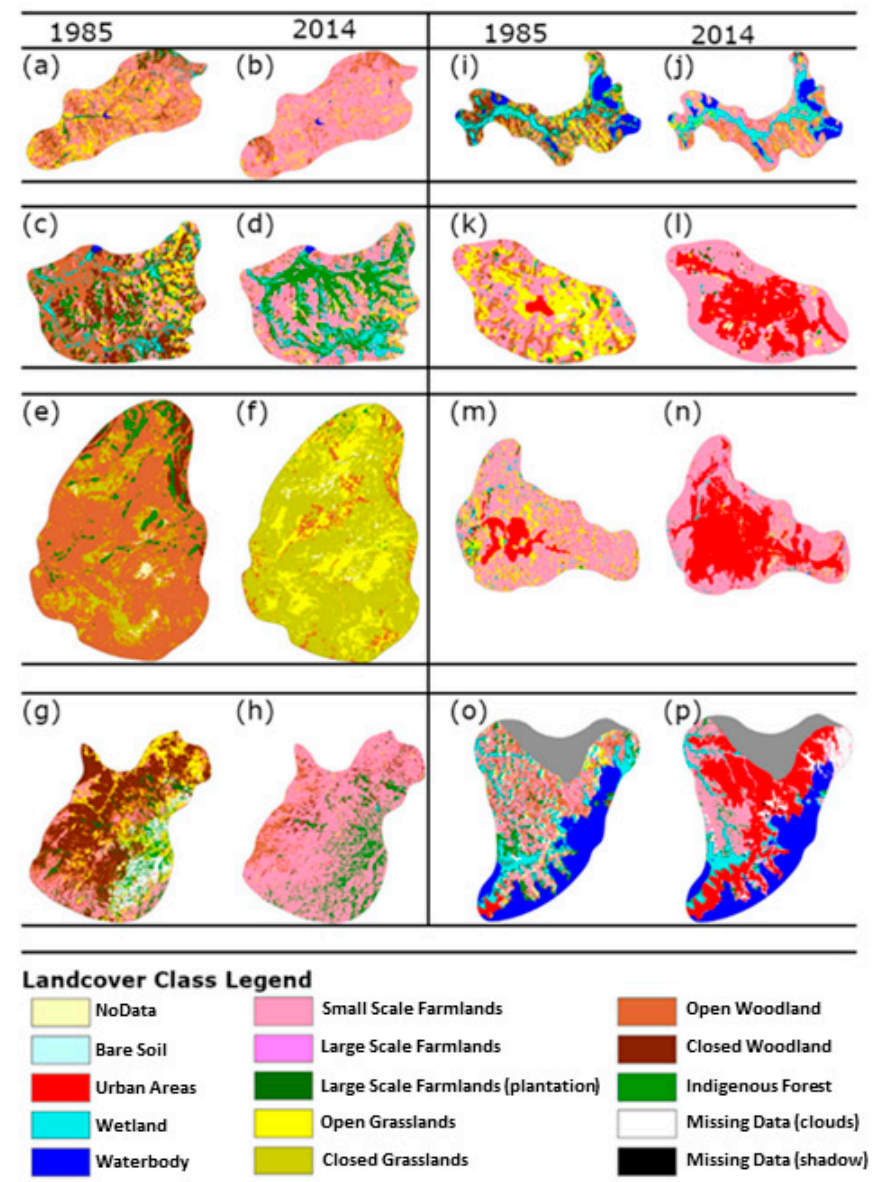

Figure 5. Selected regions of the LVB showing remarkable changes in land cover between 1985 and 2014. Letters (a-p) indicate the locations in the study area map on Figure 1. 
Our area computations were consistent with published area estimates for the Lake Victoria water mass and the LVB land mass, approximately 6 million and 18 million hectares, respectively (Table 2). From 1985, land cover land use change in the LVB is noticeable, with increases in the hectarage under small scale farmlands, urban areas, and bare soil (Table 2). Between 1985 and 2014, the urban areas grew by over $800 \%$, the bare soil by over $140 \%$, the small scale farmlands by over $90 \%$, and the large scale farmlands by $55 \%$. Furthermore, the open grasslands, open woodlands, closed woodlands, and indigenous forests declined by $41 \%, 43 \%, 75 \%$, and $44 \%$, respectively (Table 2 ). The mean area per class (shown as percentage) and the proportions associated with each year are shown in the Sankey diagram in Figure 6. We also noticed highly significant correlations between the decline in indigenous forests, open and closed woodlands, wetlands, and open grasslands and the growth in small scale farmlands. In addition, we observed significant correlations between indigenous forests, wetlands, and open grasslands and the growth in urban areas (Table 3). However, correlations between areas under open and closed woodlands and urban areas were not significant. Moreover, there is no significant correlation between the areas under large scale farmlands and closed grasslands and small scale farmlands (Table 3). The land cover maps presented in this work are hosted at the RCMRD Geoportal (http://geoportal.rcmrd.org/layers/?limit=100\&offset=0\&title_icontains=Lake\%20Victoria\% 20Basin\%20Land\%20Cover) and are publicly available, which facilitates data sharing as well as other studies focusing on similar objectives.

Land Cover Class

Year

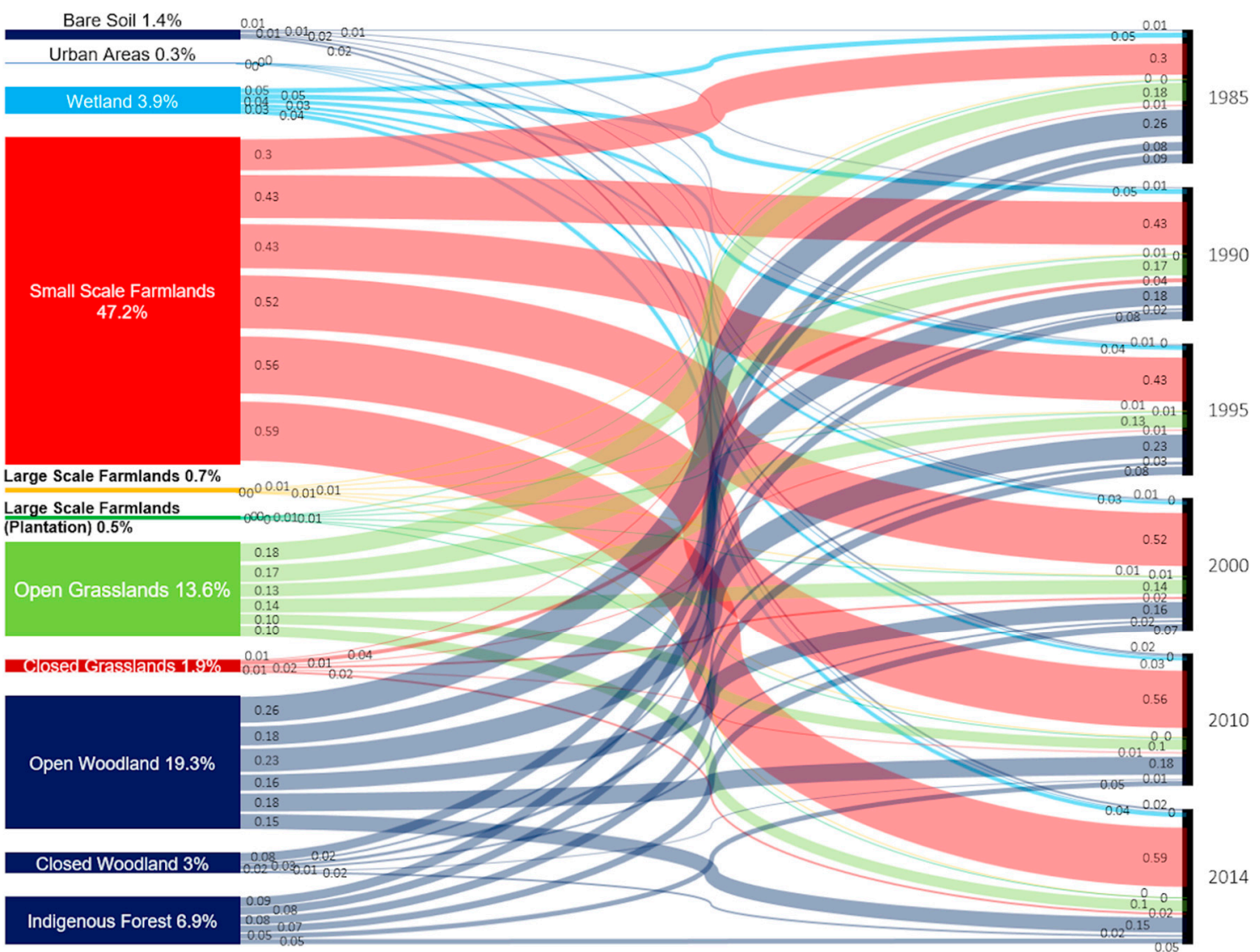

Figure 6. A Sankey diagram showing the mean proportion of area for each class, relative to the total land area for the entire LVB (around 18.7 million hectares), excluding the lake area. The proportion of each class accounted for in each year is illustrated via the line linking the class to the year on the right. 
Table 2. Land cover area (ha) for each land cover type and the corresponding percentage change normalized using the 1985 hectarage as base area.

\begin{tabular}{|c|c|c|c|c|c|c|c|c|c|c|c|c|}
\hline \multirow[b]{2}{*}{ Land Use Land Cover Class } & \multicolumn{2}{|c|}{1985} & \multicolumn{2}{|c|}{1990} & \multicolumn{2}{|c|}{1995} & \multicolumn{2}{|c|}{2000} & \multicolumn{2}{|c|}{2010} & \multicolumn{2}{|c|}{2014} \\
\hline & Area (ha) & $\%$ cover & Area (ha) & $\%$ cover & Area (ha) & $\%$ cover & Area (ha) & $\%$ cover & Area (ha) & $\%$ cover & Area (ha) & $\%$ cover \\
\hline Bare Soil & $172,139.58$ & 100.00 & $120,516.93$ & -29.99 & $225,153.99$ & 30.80 & $255,524.76$ & 48.44 & $417,997.26$ & 142.82 & $418,171.05$ & 142.93 \\
\hline Urban Areas & 8349.93 & 100.00 & $13,017.24$ & 55.90 & $25,893.45$ & 210.10 & $75,763.08$ & 807.35 & $82,715.67$ & 890.62 & $82,715.67$ & 890.62 \\
\hline Wetland & $1,016,930.07$ & 100.00 & $884,051.01$ & -13.07 & $705,837.87$ & -30.59 & $553,600.62$ & -45.56 & $519,269.04$ & -48.94 & $678,657.06$ & -33.26 \\
\hline Small Scale Farmlands & $5,656,113.81$ & 100.00 & $8,056,702.80$ & 42.44 & $8,160,745.05$ & 44.28 & $9,750,362.85$ & 72.39 & $10,565,061.03$ & 86.79 & $11,016,723.51$ & 94.78 \\
\hline Large Scale Farmlands & $55,464.12$ & 100.00 & $180,646.56$ & 225.70 & $245,862.54$ & 343.28 & $162,351.99$ & 192.72 & $77,598.72$ & 39.91 & $86,050.89$ & 55.15 \\
\hline Large Scale Farmlands (Plantation) & $89,364.06$ & 100.00 & $62,526.87$ & -30.03 & $125,390.79$ & 40.31 & $156,964.68$ & 75.65 & $81,023.85$ & -9.33 & $80,512.11$ & -9.91 \\
\hline Open Grasslands & $3,327,540.30$ & 100.00 & $3,209,778.99$ & -3.54 & $2,349,974.61$ & -29.38 & $2,642,632.56$ & -20.58 & $1,847,900.70$ & -44.47 & $1,952,168.67$ & -41.33 \\
\hline Closed Grasslands & $235,928.52$ & 100.00 & $798,322.86$ & 238.37 & $132,574.77$ & -43.81 & $406,432.08$ & 72.27 & $203,191.02$ & -13.88 & $353,555.10$ & 49.86 \\
\hline Closed Woodland & $1,583,870.58$ & 100.00 & $381,222.00$ & -75.93 & $546,869.79$ & -65.47 & $298,554.39$ & -81.15 & $198,635.76$ & -87.46 & $390,230.46$ & -75.36 \\
\hline Indigenous Forest & $1,709,343.18$ & 100.00 & $1,423,130.40$ & -16.74 & $1,433,954.43$ & -16.11 & $1,244,473.83$ & -27.20 & $971,438.04$ & -43.17 & $950,708.61$ & -44.38 \\
\hline Missing Data (Cloud) & $64,008.99$ & 100.00 & $188,510.49$ & 194.51 & $469,447.74$ & 633.41 & $272,284.92$ & 325.39 & $465,247.71$ & 626.85 & $77,376.06$ & 20.88 \\
\hline Missing Data (Shadow) & 6534.09 & 100.00 & $72,937.35$ & 1016.26 & $76,945.41$ & 1077.60 & $78,198.66$ & 1096.78 & $17,467.56$ & 167.33 & 1140.39 & -82.55 \\
\hline
\end{tabular}

Table 3. Model parameters for linear regressions run for area combinations of various land cover types: $p$ ( $p$-value); $r$ (correlation coefficient); $r^{2}$ (regression coefficient); $\mathrm{SE}$ (standard error); $\mathrm{n}$ (number of points).

\begin{tabular}{|c|c|c|c|c|c|c|c|c|}
\hline $\mathbf{Y}$ & $X$ & Coefficient & Intercept & $\mathrm{p}$ & $\mathbf{r}$ & $\mathrm{r}^{2}$ & $\mathrm{SE}$ & $\mathrm{n}$ \\
\hline Indigenous Forests & Small Scale Farmlands & -0.145 & $2,575,884.15$ & 0.00 & 0.98 & 0.96 & $65,022.76$ & 6 \\
\hline Indigenous Forests & Urban Areas & -7.512 & $1,649,966.76$ & 0.01 & 0.92 & 0.84 & $130,517.49$ & 6 \\
\hline Open Woodland & Small Scale Farmlands & -0.365 & $6,865,740.34$ & 0.02 & 0.89 & 0.78 & $426,606.19$ & 6 \\
\hline Wetlands & Urban Areas & -4.675 & $951,132.96$ & 0.02 & 0.87 & 0.76 & $104,199.08$ & 6 \\
\hline Wetlands & Small Scale Farmlands & -0.084 & $1,468,604.96$ & 0.03 & 0.87 & 0.75 & $107,662.44$ & 6 \\
\hline Open Grasslands & Small Scale Farmlands & -0.268 & $4,928,132.50$ & 0.03 & 0.85 & 0.73 & $361,996.74$ & 6 \\
\hline Open Grasslands & Urban Areas & -14.236 & $3,239,413.48$ & 0.04 & 0.82 & 0.68 & $396,317.46$ & 6 \\
\hline Closed Woodland & Urban Areas & -9.241 & $1,010,851.25$ & 0.16 & 0.65 & 0.42 & $434,669.94$ & 6 \\
\hline Large Scale Farmlands (Plantations) & Small Scale Farmlands & 0.001 & $89,064.77$ & 0.90 & 0.07 & 0.00 & $39,107.66$ & 6 \\
\hline Large Scale Farmlands & Small Scale Farmlands & -0.002 & $151,921.04$ & 0.92 & 0.05 & 0.00 & $82,255.13$ & 6 \\
\hline Closed Grasslands & Small Scale Farmlands & -0.002 & $370,833.51$ & 0.98 & 0.01 & 0.00 & $267,309.05$ & 6 \\
\hline
\end{tabular}




\section{Discussion}

The goal of this work was to assess basin scale land use land cover changes over the last 30 years (1985-2014) and thus determine trends in land use change over time and subsequent deductions in changes to ecosystem services. We used Earth observation data to look at basin scale changes in land use land cover because remote sensing data provide synoptic coverage of global landscapes and also present systematic historical records of changes for consistent comparisons. Our findings indicate that land use land cover changes in the Lake Victoria Basin are mainly driven by small scale agricultural activities and urban development (settlements). The changes in land cover and associated trends in the LVB are similar to those reported in other studies [12,13], with minor discrepancies in spatial and temporal scales of previous studies, a shortcoming that we counterbalanced in our basin wide, 30-year study. While comparing our maps with the maps produced by the European Space Agency Climate Change Initiative (ESA-CCI) land cover project (http://maps.elie.ucl.ac.be/CCI/viewer/index.php) for the LVB in 2014, we also noted similarities, particularly in the classification of farmlands (croplands). However, the ESA-CCI maps were produced at 300-m resolution and present far more disaggregated land cover classes than our maps. Our results indicated overall accuracy of $71 \%$, which is slightly below the $80-85 \%$ reasonable limit recommended for overall accuracy of land cover estimates derived from remotely sensed data [24], but similar to results obtained by previous studies in the region using Landsat and MODIS datasets [4,25]. A number of factors can potentially affect the overall accuracy of land cover classifications. Key among them are classifier selection and class distribution in the training dataset [26], as well as the accuracy of the ground reference dataset [27], sampling issues, errors in classification, and accuracy data sampling. Other factors also include heterogeneity of landscapes with complex land cover mosaics and misrepresentation and misinterpretation of the temporal sequence of remotely sensed imagery [28]. We suppose that the accuracy of our classifications could have been affected by the sample size of reference data and the heterogeneity of the land cover mosaic in the LVB, where fine land cover classes can be challenging to disaggregate. Indeed, other researchers within the basin have argued that classification error rates are lower for datasets with fewer land cover classes [25]. However, we feel that our results represent an important piece of knowledge, given that basin wide land cover classifications for the classes that we considered, over a period of 30 years, are rare. Other regional and/or global land cover maps do not provide the same temporal scale, standardized method across time, or spatial resolution to effectively assess LC dynamics in $\operatorname{LVB}[4,23]$.

The drivers of land use change are complex in the LVB, just like elsewhere in developing countries [7]. Land use land cover changes in the LVB have implications for water quality degradation in Lake Victoria, as well as causing a decline in the quality of ecosystem services within the catchment and the lake [17]. Our findings on land cover changes and trends can be explained largely by population growth and expansion of socioeconomic activities in the basin (e.g., agriculture, livestock keeping), demand for natural resources to support economic growth (timber, papyrus, and minerals), climate variability and natural disasters, and infrastructure development [7]. Governance, too, is also a key factor around these issues. The Lake Victoria Basin is one of the regions in East Africa with the highest population density [29], averaging approximately 500 persons per $\mathrm{km}^{2}$, and, in some parts of Kenya, densities of up to 1200 persons per $\mathrm{km}^{2}$ have been reported [1]. The basin is home to over 30 million people [30] whose livelihoods depend mainly on agriculture and livestock production, beekeeping, mining, trade, and fishing [9]. Consequently, agricultural expansion and intensification, land degradation, and other anthropogenic activities are key agents of land use change in the basin. As the demand for food grows, land in the basin continues to be subdivided for small scale agriculture and settlement, leading to an increase in small farms and urban centers [9]. Expansion and intensification of agriculture (mechanization and fertilizer inputs) and increases in livestock numbers also render the land more prone to erosion [9]. With the influx of people in urban areas, there is increased demand for services and construction materials such as timber and building stones and fuel wood [31], which further drives conversion of forests and woodlands to either grasslands or farmlands [32] and 
quarries to bare ground [33]. Interestingly, we found significant inverse correlations between expansion of small scale farmlands and contraction of indigenous forests, grasslands, woodlands, and wetlands, consistent with previous findings [9] relating to a section of the LVB. This confirms that expansion of small scale agricultural activities is contributing to loss of indigenous vegetation. These dynamics are challenging to land use planners throughout Africa, where the urban population is expected to reach around 1.3 billion people by 2050, corresponding to $21 \%$ of the world's projected urban population [34].

The LVB has one of the highest rates of urban expansion in Africa [5]. While the land under urban areas in Africa is projected to increase by nearly 600\% between 2000 and 2030 [5], our results show that, for the LVB, the area under urban land has increased [35] by over $800 \%$, which may indicate that the expansion of urban areas within the basin is higher than the continental average. The growth in urban areas from small towns to cities comes with major needs for infrastructure to service not only the urban populace but also the urban-rural interactions. The needs include higher demands for food (irrigation, livestock, fisheries, and aquaculture projects), housing, energy (electricity and fuel wood), transport, healthcare, schools (primary to tertiary), security and governance, communication, flood control structures, and solid and liquid waste treatment plants, etc. All this infrastructure (or part of it) constitutes the modern-day infrastructural layouts in urban centers. The development of such infrastructure which is intended to support current and future populations is competing for the same amount of land resources. Our results indicate highly significant $(p<0.05)$ and strong inverse correlations between the area under urban centers and area under indigenous forests, wetlands, and open grasslands over the years. This implies that urban growth is contributing to the loss of forests, wetlands, and grasslands, either through increased demand for space, materials, or repositories for waste, which leads to land use change, fragmentation, or degradation. Furthermore, we found a highly significant $(p<0.05)$ and strong positive correlation between the area under urban centers and small scale farmlands. While this may appear an unusual finding, it can be explained by the need to substitute the land taken up by urban areas with new farmlands, hence conversions from other classes to farmlands. This could imply that both the expansion of urban centers and small scale farmlands is taking place at the expense of other land cover classes, and the scale of such conversions can certainly be guided by data-based government policy [36]. It is also true that the demand for land in these two classes is often driven by very similar or the same dynamics. From these findings, it is important for the five states sharing the LVB to encourage drafting, implementation, and frequent review of spatial land use plans across the basin. Spatial land use plans would help governments and stakeholders to have a consolidated and long-term plan for the smaller administrative units that constitute the basin in each of the countries. Where such plans exist and have been implemented with a reasonable degree of success, they could be used as blueprints for drafting spatial plans for other areas. At present, medium to high resolution Earth observation data would be an important complimentary dataset to other sets of information required to compile a comprehensive spatial land use plan. Ultimately, solving the problem of ad hoc land use changes would go a long way in aligning infrastructure development with development plans for the basin and minimize conversions of land use from one use to another without considerations for long-term sustainability.

The LVB is well endowed with natural capital such as forests, woodlands, grasslands, minerals, large rivers, wetlands, fisheries, and fertile farmlands whose demand continues to rise. Efforts to quantify and document the value of the natural capital within the basin have shown promising results [36]. These resources support livelihoods and thriving international trade [1] within the five states that share the LVB. The implications of land use land cover change on different sectors of the economy, such as agriculture and livestock production and mining [9,17], are now evident and can be discussed at length. The basin's economic growth and development is to a large extent dependent on the availability of natural resources, land being one of the key resources in this region. The fundamental question for the LVB (like other regions in Africa) is this: can the basin manage positive economic growth and development and still preserve the ecological services from its natural landscapes? Besides growth related pressures on natural resources, it is also important to consider 
external factors which affect the natural resource base and drive land cover change. Natural disasters such as wild fires and landslides can cause significant changes in land cover, and, without sufficient time for the ecosystem to recover, it can lead to permanent changes, which exposes the land to further degradation [37]. Forest and savannah fires are reported in the basin especially during prolonged droughts [11]. Furthermore, instability in governance in any one of the countries could trigger civil conflict and cause an influx of refugees or internally displaced persons who exert pressure on natural resources such as woodlands for fuelwood and construction of temporary shelters, fresh water, and land for cultivation [5]. In addition, foreign direct investments on large scale agriculture could also spur land use land cover change [5].

Climate variability and climate related natural disasters have also contributed to land use land cover change in the basin over the years [38]. Droughts in the basin affect food production, availability of water, and generation of hydroelectric power [39]. Severe droughts also affect vegetation and thus increase the percentage of bare ground exposed to agents of erosion. After extreme drought, some vegetation types take much longer to recover [38] and could even give way for colonization of the landscapes by invasive species. According to one study [32], the LVB is a significant hotspot where people suffer from exceptionally high exposure to climate change impacts, primarily due to the collocation of population increase on lands with decreasing rainfall. Besides droughts, parts of the basin also experience flooding, often with catastrophic consequences. Extreme flooding is known to inundate productive land, thus affecting the production cycles, as well as causing massive erosion, destruction of property, and loss of lives [40]. On the contrary, partial flooding could be beneficial for vegetation recovery in drylands [37]. Parts of the basin in Rwanda and Burundi are also highly susceptible to landslides during periods of extreme rainfall [41]. The land related issues surrounding drought and flooding cycles in the basin could partly explain the demand for land cover conversions from indigenous forests, woodlands, grasslands, and wetlands to small scale farming and settlement.

Mitigating the impacts of land use land cover change on ecosystem services of the Lake Victoria Basin has been ongoing work for many years, particularly under the umbrella of the East Africa Community, the Lake Victoria Basin Commission, and other national level agencies. The details of these efforts are beyond the scope of this paper and are adequately addressed elsewhere [3]. However, it is worth pointing out that our findings indicate that the major drivers of land use change in the LVB have a strong human dimension, particularly in connection to the demand for food production and settlement [42]. Any future efforts to address the impacts of land use change would need to intensify measures to address needs around these two factors.

Our work was subject to certain limitations that are worth highlighting. Firstly, we used 30-m Landsat data, which might have challenges in resolving fine changes in land cover change and can introduce errors. Secondly, optical data are subject to interference by clouds, and even though the percentage of cloud cover relative to the entire basin is small, it could still influence the computation of total area under a land cover class. We made efforts to select imagery with as little cloud cover as practically possible. However, we acknowledge that algorithms to generate cloud free mosaics of Landsat imagery are available (e.g., under Google Earth Engine platform). Using a near cloud free mosaic of Landsat data could change the results slightly, but probably not the trends. Thirdly, our results are at basin scale and the land cover class definitions could vary slightly when interpretations are made at national or sub-national levels. The overall accuracy $(71 \%)$ was slightly below the recommended threshold of $85 \%$ for land cover classifications from remote sensing data [24]. Previous studies have come up with similar results for work within the basin and attributed those results to classification error rates being lower for datasets with fewer land cover classes [25]. In addition, the accuracy could improve if a bigger sample of reference data was obtained. In our work, this was constrained by project timelines, reference data collection logistics, and funding. 


\section{Conclusions}

Satellite remote sensing data analyzed for the LVB over a period of 30 years show significant impact of human activities on land use land cover for the basin. Key among the drivers of land use land cover for the basin are urban growth and expansion of agriculture at the expense of forests, grasslands, and woodlands. This predisposes the land to severe erosion and pollution of aquatic environments, which has been witnessed in the basin over the years.

The utility and value of information from our work can be two-fold: (i) for monitoring land use land cover changes over time and therefore providing empirical estimates of the changes and drivers of land cover change for decision making; (ii) design of a targeted and prioritized ecosystem restoration system whose investments, achievements, and gains can be measured using Earth observation data and other socioeconomic metrics. In addition to the elaborate regional strategic action plans addressing landscape restoration, conservation, waste management, soil conservation, and improved farming practices, we recommend adoption of a basin scale, operational, Earth observation-based, land cover and land use change monitoring framework. Such a framework can facilitate rapid and frequent assessments of gains and losses in specific land cover classes and thus focus strategic interventions in areas experiencing major losses, through mitigation and compensatory approaches. Cognizant of the relentless fragmentation and modification of natural land cover (forests, grasslands, wetlands) through conversions to other land uses, and the realization that the LVB land use plans fall under various jurisdictions, we are of the opinion that successful basin scale land use management efforts will benefit immensely from coordinated national, sub-national, and community level inputs. Here, we propose that Earth observation (EO) data analysis, outputs, and tools should move beyond quantifying the magnitude of the problem, to facilitating design and refinement of community level targeting, prioritization, monitoring, and restoration efforts. In areas where land cover has changed from one class to another, but the land use has not changed officially, assessing the societal cost of restoration is important. In other areas, it may be argued that some of the land use changes witnessed in the basin are radical (e.g., 100-hectare forest converted to farmlands which are eventually turned into fragmented settlements) and therefore cannot be reversed through restoration. While this is true, through spatial analysis and community level consultations, authorities could explore compensatory approaches to identify and prioritize the restoration and connectivity of fragmented units (forests, grasslands, woodlands, etc.) whose total area could equal that lost from the conversion of large units of homogenous land cover classes. The fragmented sets of such units could be designed to offer complimentary ecosystem services lost from destruction of larger homogenous and contiguous natural land cover, where economic, environmental, and social considerations are optimized. Such an approach can be practically supported by an operational EO-based land use land cover assessment tool which regularly provides estimates of losses and gains in key land cover classes for the basin and thus influences short to long-term decision making. Dissemination of such information on web-based platforms which can be accessed via mobile computing devices can greatly improve accessibility of the data and information and thus foster evidence-based decision making.

Author Contributions: Conceptualization, R.M., J.W.N. and A.I.F.-A.; methodology, R.W., J.W.N., A.N.; validation, R.W., A.N. and J.W.N.; formal analysis, R.W., J.W.N., A.N., R.M.; writing-original draft preparation, R.M., R.W., J.W.N., E.C.A.; writing-review and editing, A.N., A.I.F.-A.; visualization, J.W.N.; supervision, E.C.A., A.I.F.-A., R.M.; project administration, R.M., A.I.F.-A.; funding acquisition, RCMRD. All authors have read and agreed to the published version of the manuscript.

Funding: This research was funded by the United States Agency for International Development (USAID) and the National Aeronautics and Space Agency (NASA) through the SERVIR Eastern \& Southern Africa project, grant number AID-EGEE-IO-15-00002, awarded to the Regional Centre for Mapping of Resources for Development (RCMRD). 
Acknowledgments: This work was supported by the United States Agency for International Development (USAID) and the National Aeronautics and Space Agency (NASA) through the SERVIR Eastern \& Southern Africa project. Data collection and analysis was also supported by the Regional Centre for Mapping of Resources for Development (RCMRD). SERVIR is a partnership between USAID, NASA, and RCMRD which promotes the use of Earth observation information for development decision making. We appreciate the use of Landsat satellite data from the USGS. We are also indebted to our partners in Uganda (NAFFIRI) and Tanzania (TAFIRI) for helping in field work on validation points for land cover change. We also appreciate the invaluable input of anonymous reviewers who helped to improve the quality of the manuscript.

Conflicts of Interest: The authors declare no conflict of interest.

\section{References}

1. Odada, E.O.; Ochola, W.O.; Olago, D.O. Drivers of ecosystem change and their impacts on human well-being in Lake Victoria basin. Afr. J. Ecol. 2009, 47, 46-54. [CrossRef]

2. Wanink, J.H.; Goudswaard, K.P.C. Effects of Nile perch (Lates niloticus) introduction into Lake Victoria, East Africa, on the diet of Pied Kingfishers (Ceryle rudis). Hydrobiologia 1994, 279, 367-376. [CrossRef]

3. Muyodi, F.J.; Bugenyi, F.W.B.; Hecky, R.E. Experiences and lessons learned from interventions in the Lake Victoria Basin: The Lake Victoria Environmental Management Project: Experiences and lessons in L. Victoria. Lakes Reserv. Res. Manag. 2010, 15, 77-88. [CrossRef]

4. Al-Hamdan, M.Z.; Oduor, P.; Flores, A.I.; Kotikot, S.M.; Mugo, R.; Ababu, J.; Farah, H. Evaluating land cover changes in Eastern and Southern Africa from 2000 to 2010 using validated Landsat and MODIS data. Int. J. Appl. Earth Obs. Geoinf. 2017, 62, 8-26. [CrossRef]

5. Güneralp, B.; Lwasa, S.; Masundire, H.; Parnell, S.; Seto, K.C. Urbanization in Africa: Challenges and opportunities for conservation. Environ. Res. Lett. 2017, 13, 015002. [CrossRef]

6. Marchant, R.; Richer, S.; Boles, O.; Capitani, C.; Courtney-Mustaphi, C.J.; Lane, P.; Prendergast, M.E.; Stump, D.; De Cort, G.; Kaplan, J.O.; et al. Drivers and trajectories of land cover change in East Africa: Human and environmental interactions from 6000 years ago to present. EarthSci. Rev. 2018, 178, 322-378. [CrossRef]

7. Osinubi, S.T.; Hand, K.; Van Oijen, D.C.C.; Walther, B.A.; Barnard, P. Linking science and policy to address conservation concerns about African land use, land conversion and land grabs in the era of globalization. Afr. J. Ecol. 2016, 54, 265-267. [CrossRef]

8. Midekisa, A.; Holl, F.; Savory, D.J.; Andrade-Pacheco, R.; Gething, P.W.; Bennett, A.; Sturrock, H.J.W. Mapping land cover change over continental Africa using Landsat and Google Earth Engine cloud computing. PLoS ONE 2017, 12, e0184926. [CrossRef]

9. Kashaigili, J.J.; Zziwa, E.; Ernest, S.; Laswai, E.; Segatagara, B.M.; Mpairwe, D.; Kadigi, R.M.J.; Ebong, C.; Mugasi, S.K.; Laswai, G.H.; et al. Implications of Land Use Land Cover Change and Climate Variability on Future Prospects of Beef Cattle Production in the Lake Victoria Basin. Am. J. Clim. Chang. 2015, 4, 461-473. [CrossRef]

10. Wasige, J.E.; Groen, T.A.; Smaling, E.; Jetten, V. Monitoring basin-scale land cover changes in Kagera Basin of Lake Victoria using ancillary data and remote sensing. Int. J. Appl. Earth Obs. Geoinf. 2013, 21, 32-42. [CrossRef]

11. Nelson, D.M.; Verschuren, D.; Urban, M.A.; Hu, F.S. Long-term variability and rainfall control of savanna fire regimes in equatorial East Africa. Glob. Chang. Biol. 2012, 18, 3160-3170. [CrossRef] [PubMed]

12. Berakhi, R.O.; Oyana, T.J.; Adu-Prah, S. Land use and land cover change and its implications in Kagera river basin, East Africa. Afr. Geogr. Rev. 2015, 34, 209-231. [CrossRef]

13. Kiggundu, N.; Anaba, L.A.; Banadda, N.; Wanyama, J.; Kabenge, I. Assessing Land Use and Land Cover Changes in the Murchison Bay Catchment of Lake Victoria Basin in Uganda. J. Sustain. Dev. 2018, 11, 44. [CrossRef]

14. Tatem, A.J.; Noor, A.M.; Von Hagen, C.; Di Gregorio, A.; Hay, S.I. High Resolution Population Maps for Low Income Nations: Combining Land Cover and Census in East Africa. PLoS ONE 2007, 2, e1298. [CrossRef]

15. De Meyer, A.; Poesen, J.; Isabirye, M.; Deckers, J.; Raes, D. Soil erosion rates in tropical villages: A case study from Lake Victoria Basin, Uganda. CATENA 2011, 84, 89-98. [CrossRef] 
16. Lufafa, A.; Tenywa, M.M.; Isabirye, M.; Majaliwa, M.J.G.; Woomer, P.L. Prediction of soil erosion in a Lake Victoria basin catchment using a GIS-based Universal Soil Loss model. Agric. Syst. 2003, 76, 883-894. [CrossRef]

17. Kundu, R.; Aura, C.M.; Nyamweya, C.; Agembe, S.; Sitoki, L.; Lung'ayia, H.B.O.; Ongore, C.; Ogari, Z.; Werimo, K. Changes in pollution indicators in Lake Victoria, Kenya and their implications for lake and catchment management. Lakes Reserv. Res. Manag. 2017, 22, 199-214. [CrossRef]

18. Marchant, R.; Mumbi, C.; Behera, S.; Yamagata, T. The Indian Ocean dipole? The unsung driver of climatic variability in East Africa. Afr. J. Ecol. 2007, 45, 4-16. [CrossRef]

19. Saji, N.H.; Goswami, B.N.; Vinayachandran, P.N.; Yamagata, T. A dipole mode in the tropical Indian Ocean. Nature 1999, 401, 360-363. [CrossRef]

20. Nyamweya, C.S.; Natugonza, V.; Taabu-Munyaho, A.; Aura, C.M.; Njiru, J.M.; Ongore, C.; Mangeni-Sande, R.; Kashindye, B.B.; Odoli, C.O.; Ogari, Z.; et al. A century of drastic change: Human-induced changes of Lake Victoria fisheries and ecology. Fish. Res. 2020, 230, 105564. [CrossRef]

21. Ahlqvist, O. In Search of Classification that Supports the Dynamics of Science: The FAO Land Cover Classification System and Proposed Modifications. Environ. Plan. B Plan. Des. 2008, 35, 169-186. [CrossRef]

22. Olofsson, P.; Foody, G.M.; Herold, M.; Stehman, S.V.; Woodcock, C.E.; Wulder, M.A. Good practices for estimating area and assessing accuracy of land change. Remote Sens. Environ. 2014, 148, 42-57. [CrossRef]

23. Hansen, M.C.; Potapov, P.V.; Moore, R.; Hancher, M.; Turubanova, S.A.; Tyukavina, A.; Thau, D.; Stehman, S.V.; Goetz, S.J.; Loveland, T.R.; et al. High-Resolution Global Maps of $21^{\text {st }}$-Century Forest Cover Change. Science 2013, 342, 850-853. [CrossRef] [PubMed]

24. Treitz, P.; Rogan, J. Remote sensing for mapping and monitoring land-cover and land-use changeAn introduction. Prog. Plan. 2004, 61, 269-279. [CrossRef]

25. Bagstad, K.J.; Ingram, J.C.; Lange, G.; Masozera, M.; Ancona, Z.H.; Bana, M.; Kagabo, D.; Musana, B.; Nabahungu, N.L.; Rukundo, E.; et al. Towards ecosystem accounts for Rwanda: Tracking 25 years of change in flows and potential supply of ecosystem services. People Nat. 2020, 2, 163-188. [CrossRef]

26. Heydari, S.S.; Mountrakis, G. Effect of classifier selection, reference sample size, reference class distribution and scene heterogeneity in per-pixel classification accuracy using 26 Landsat sites. Remote Sens. Environ. 2018, 204, 648-658. [CrossRef]

27. Foody, G.M. Assessing the accuracy of land cover change with imperfect ground reference data. Remote Sens. Environ. 2010, 114, 2271-2285. [CrossRef]

28. Foody, G.M. Status of land cover classification accuracy assessment. Remote Sens. Environ. 2002, 80, $185-201$. [CrossRef]

29. Ntiba, M.J.; Kudoja, W.M.; Mukasa, C.T. Management issues in the Lake Victoria watershed. Lakes Reserv. Res. Manag. 2001, 6, 211-216. [CrossRef]

30. Virts, K.S.; Goodman, S.J. Prolific Lightning and Thunderstorm Initiation over the Lake Victoria Basin in East Africa. Mon. Weather Rev. 2020, 148, 1971-1985. [CrossRef]

31. Kiruki, H.M.; Zanden, E.H.; Malek, Ž.; Verburg, P.H. Land Cover Change and Woodland Degradation in a Charcoal Producing Semi-Arid Area in Kenya. Land Degrad. Dev. 2017, 28, 472-481. [CrossRef]

32. López-Carr, D.; Pricope, N.G.; Aukema, J.E.; Jankowska, M.M.; Funk, C.; Husak, G.; Michaelsen, J. A spatial analysis of population dynamics and climate change in Africa: Potential vulnerability hot spots emerge where precipitation declines and demographic pressures coincide. Popul. Environ. 2014, 35, 323-339. [CrossRef]

33. Edwards, D.P.; Sloan, S.; Weng, L.; Dirks, P.; Sayer, J.; Laurance, W.F. Mining and the African Environment: Mining and Africa's environment. Conserv. Lett. 2014, 7, 302-311. [CrossRef]

34. Cobbinah, P.B.; Erdiaw-Kwasie, M.O.; Amoateng, P. Africa's urbanisation: Implications for sustainable development. Cities 2015, 47, 62-72. [CrossRef]

35. Mugiraneza, T.; Ban, Y.; Haas, J. Urban land cover dynamics and their impact on ecosystem services in Kigali, Rwanda using multi-temporal Landsat data. Remote Sens. Appl. Soc. Environ. 2019, 13, 234-246. [CrossRef]

36. Stage, J.; Uwera, C. Prospects for establishing environmental satellite accounts in a developing country: The case of Rwanda. J. Clean. Prod. 2018, 200, 219-230. [CrossRef]

37. Pricope, N.; Gaughan, A.; All, J.; Binford, M.; Rutina, L. Spatio-Temporal Analysis of Vegetation Dynamics in Relation to Shifting Inundation and Fire Regimes: Disentangling Environmental Variability from Land Management Decisions in a Southern African Transboundary Watershed. Land 2015, 4, 627-655. [CrossRef] 
38. Ruppert, J.C.; Harmoney, K.; Henkin, Z.; Snyman, H.A.; Sternberg, M.; Willms, W.; Linstädter, A. Quantifying drylands' drought resistance and recovery: The importance of drought intensity, dominant life history and grazing regime. Glob. Chang. Biol. 2015, 21, 1258-1270. [CrossRef]

39. Awange, J.; Aluoch, J.; Ogallo, L.; Omulo, M.; Omondi, P. Frequency and severity of drought in the Lake Victoria region (Kenya) and its effects on food security. Clim. Res. 2007, 33, 135-142. [CrossRef]

40. Kundu, P.M.; Olang, L.O. The impact of land use change on runoff and peak flood discharges for the Nyando River in Lake Victoria drainage basin, Kenya. Water Soc. 2011, 83-94. [CrossRef]

41. Nsengiyumva, J.; Luo, G.; Nahayo, L.; Huang, X.; Cai, P. Landslide Susceptibility Assessment Using Spatial Multi-Criteria Evaluation Model in Rwanda. Int. J. Environ. Res. Public Health 2018, 15, 243. [CrossRef] [PubMed]

42. Rukundo, E.; Liu, S.; Dong, Y.; Rutebuka, E.; Asamoah, E.F.; Xu, J.; Wu, X. Spatio-temporal dynamics of critical ecosystem services in response to agricultural expansion in Rwanda, East Africa. Ecol. Indic. 2018, 89, 696-705. [CrossRef]

(C) 2020 by the authors. Licensee MDPI, Basel, Switzerland. This article is an open access article distributed under the terms and conditions of the Creative Commons Attribution (CC BY) license (http://creativecommons.org/licenses/by/4.0/). 